\title{
Predictive model of Amorphophallus muelleri growth in some agroforestry in East Java by multiple regression analysis
}

\author{
BUDIMAN" ENDANG ARISOESILANINGSIH \\ Department of Biology, Faculty of Mathematics and Natural Sciences, University of Brawijaya, Malang 65145, East Java, Indonesia. Tel. \& Fax.: +62- \\ 341-575841. "email: budiman071287@gmail.com
}

Manuscript received: 10 December 2010. Revision accepted: 3 October 2011

\begin{abstract}
Budiman, Arisoesilaningsih E. 2012. Predictive model of Amorphophallus muelleri growth in some agroforestry in East Java by multiple regression analysis. Biodiversitas 13:00-00. This research aimed to determine the multiple regression models of vegetative and corm growth of Amorphophallus muelleri Blume in some age variations and habitat conditions of agroforestry in East Java. Descriptive exploratory research method was conducted by systematic random sampling at five agroforestries on four plantations in East Java: Saradan, Bojonegoro, Nganjuk and Blitar. In each agroforestry, we observed A. muelleri vegetative and corm growth on four growing age (1,2, 3 and 4 years old) as well as environmental variables such as altitude, vegetation, climate and soil conditions. Data were analyzed using descriptive statistics to compare A. muelleri habitat in five agroforestries. Meanwhile, the influence and contribution of each environmental variable to the growth of A. muelleri vegetative and corm were determined using multiple regression analysis of SPSS 17.0. The multiple regression models of A. muelleri vegetative and corm growth were generated based on some characteristics of agroforestries and age showed high validity with $\mathrm{R} 2=88-99 \%$. Regression model showed that age, monthly temperatures, percentage of radiation and soil calcium $(\mathrm{Ca})$ content either simultaneously or partially determined the growth of A. muelleri vegetative and corm. Based on these models, the A. muelleri corm reached the optimal growth after four years of cultivation and they will be ready to be harvested. Additionally, the soil Ca content should reach 25.3 me.hg-1 as Sugihwaras agroforestry, with the maximal radiation of $60 \%$.
\end{abstract}

Key words: prediction, A. muelleri growth, agroforestry, regression model.

\section{INTRODUCTION}

Amorphophallus muelleri Blume, syn. A. blumei (Schott) Engler; syn. A. oncophyllus Prain; syn. A. burmanicus Hook.f. is a tropical native corm plants are included in the family of Araceae (Jansen et al. 1996; Perum Perhutani of KPH Saradan 2007). This perennial herbs have corm which can produce flour with high glucomannan level (until $75 \%$ ), much higher than in the commonly grown species such as A. konjac and A. bulbifer. The maximum viscosity could be over $40000 \mathrm{mPa}$ with good transparency of the colloid solution from glucomannan extracted (Zhang and Wang 2010). The A. muelleri flour can be modified into various processed food products such as meatballs, chips, cookies, noodles (shirataki), rangginang and tofu (konyaku). Moreover, A. muelleri corms also can be used in cosmetics, textiles and pharmaceuticals (Prihatyanto 2007; Bayu 2008a).

Due to the high economic potency of A. muelleri corms, many people started to cultivate it. A. muelleri cultivation is conducted in simple agroforestry systems, as secondary crops under the teak, mahogany or sonokeling plantation in Perum Perhutani land (Perum Perhutani of East Java 2008). The conditions of agroforestry are suitable for A. muelleri growth that have well-developed under the auspices of 5060\% (Jansen et al. 1996). Currently, the total area of $A$. muelleri cultivation in East Java exceed 1605.3 hectares and is spreading across Kesatuan Pemangkuan Hutan or Forest Management District (KPH/FMD), covering KPH North Banyuwangi, Blitar, Bojonegoro, Jember, Nganjuk, Madiun, Padangan, Purwodadi and Saradan (Perum Perum Perhutani of East Java 2008). In each hectare area, at least four tons of wet corms per year are produced and in an intensive cultivation, A. muelleri corm production reach 89 tons (Suryadi 2008) and even 12 tons of wet corm or 1.5 tons of dry corm per year (Prihatyanto 2007).

Nevertheless, the production of A. muelleri corm still has not met the standards of local and international market yet (Japan, China, Taiwan, Korea, Europe and Canada), which exceeds 9,000 tons of wet corm and 1,000 tons of dry corm slices per year. It is caused by A. muelleri cultivation system applied produces inconsistency corm sizes, which still found a corm's weight less than $1 \mathrm{~kg}$ and sometimes in a hectare of cultivation area only produces 4 tons of wet corms (Bayu 2008a, b ; Suryadi 2008).

Inconsistency A. muelleri corm production is closely linked with genetic variations and environmental conditions where A. muelleri grown. Based on DNA sequence analysis, it is known that A. muelleri in KPH Saradan, Bojonegoro, Blitar and Nganjuk have low genetic variations (S. Indriyani, 2009, pers. comm.). It is caused by the culture of A. muelleri have done vegetatively, using corm and bulbil. Additionally, A. muelleri grown in East Java, mostly from the same seeds, from Klangon 
cultivation (Arisoesilaningsih et al. 2010). Meanwhile, the location of each A. muelleri plantation unit (KPH) in East Java have the altitudes, climates, soil and vegetation is different and is predicted to interfere A. muelleri growth (Budiman et al. 2010). In addition, the age factor has affected $A$. muelleri growth as well. Therefore, this study is required to clarify the influence and contribution of environmental factors and age on A. muelleri growth in cultivation system.

The influence and contribution of environmental factors and age on A. muelleri growth can be identified by a regression model. This model is used to describe the pattern of relationships between a response variable with some predictor variables (Hair et al. 1998). Additionally, this model also predicts the value of one variable related to other variables, identified through a linear regression equation (Hasan 2008) so it can be used for optimization. Accordingly, this research aims to design multiple regression model of $A$. muelleri growth which can be used as a predictor in determining the key variables affecting the A. muelleri corm productivity in a cultivation system.

\section{MATERIALS AND METHODS}

Descriptive exploratory research method was conducted using systematic random sampling. Sampling of $A$. muelleri and soil was performed in March until May 2009 at five A. muelleri agroforestries of Perum Perhutani in East Java, which were Klangon Village (KPH Madiun), Bendoasri and Sugihwaras Village (KPH Nganjuk), Kalirejo Village (KPH Blitar) and Klino Village (KPH Bojonegoro).

In each agroforestry, we observed $A$. muelleri growth at the age of 1,2, 3 and 4 years old in opened and shaded areas in triplicates. A. muelleri age determined based on the patterns of petiole branching, namely: (i) at one year, has one base of branching, (ii) at two years, has four bases of branching; (iii) at three years, has ten bases of branching and (iv) at four years, has 22 bases of branching. A. muelleri age was determined as described by Sumarwoto (2005), namely: (i) at one year, has $20-50 \mathrm{~cm}$ of petiole height and 50-200 $\mathrm{g}$ of corm weight, (ii) at two years, has $40-75 \mathrm{~cm}$ of petiole height and 250-1350 g of corm weight, (iii) at three years, has $75-175 \mathrm{~cm}$ of petiole height and 450-3350 g of corm weight.

Amorphophallus muelleri growth was determined by petiole height, canopy diameter, number of bulbils, corm thick, corm diameter, corm weight and corm volumes. Then, A. muelleri habitats were observed including altitude measured by Global Positioning System (GPS), the percentage of plant coverage, microclimate and soil sampling. Microclimate conditions observed including percentage of radiation (measured using solarimeter), precipitations and temperatures. The data of precipitations and temperatures were obtained from Meteorology, Climatology and Geophysics Agency at Karangploso Malang, from October to December 2008 and January to April 2009. The observations of soil characteristics used a drill soil sampling (analysis of organic matter contents, cation exchange capacity (CEC), $\mathrm{Ca}$ content, $\mathrm{pH}$ and conductivity) and soil ring (density). Soil organic matters were measured by volumetry, CEC was measured by flame photometry, Ca content was measured by EDTA titration and soil density was measured by cylindrical method.

The influence and contribution of predictor variables towards response variables were determined by multiple regression models. The models were designed using SPSS 17.0 with a stepwise method. The modeling was conducted in two steps of regression test, namely: (1) between the predictor variables (environmental indicators) with the transition variables (A. muelleri vegetative growth indicators) so that obtained multiple regression model of A. muelleri vegetative growth and (2) between transition variables with response variables (A. muelleri corm growth indicators), so a multiple regression model of A. muelleri corm growth was generated. Following this, a substitution model between $A$. muelleri vegetative growth models with corm growth models was performed. Furthermore, the examination of validity of regression models was determined by determination coefficient $\left(R^{2}\right)$ value, regression coefficient and some assumptions, which were: (i) normality of residues is known through KolmogorovSminov; (ii) linearity of model is identified by curve estimation; (iii) non multicollinearity is known through Variance Inflation Factor (VIF) value and (iv) homoscedaticity is known through Spearman Rank correlation test (Table 1). The models that have not met the assumptions must be evaluated. Evaluations the regression models can be conducted with were not include one of variables causes multicollinearity and transforming the variables have heteroscedasticity and unnormal residual into $\log$ form.

Table 1. The provisions for each indicator in determining the validity of regression models

\begin{tabular}{ll}
\hline Indicator & Provision \\
\hline $\mathrm{R}^{2}$ & $\$ 80 \%$ \\
F test for determining the simultaneously influence X to $\mathrm{Y}$ p-value $<0.05$ \\
t test for determining the partially influence X to Y & $\mathrm{p}$-value $<0.05$ \\
Non multicollinearity using VIF value & $<5$ \\
Normality of residual using Kolmogorov-Sminov & $\mathrm{p}$-value $>0.05$ \\
Homoscedaticity using Spearman Rank correlation test & $\mathrm{p}$-value $>0.05$ \\
Linearity of model using curve estimation & $\mathrm{p}$-value $<0.05$ \\
\hline
\end{tabular}

\section{RESULTS AND DISCUSSION}

\section{Models of A. muelleri growth in some agroforestries}

The evaluation of regression models indicate that age, monthly temperature, percentage of radiation and soil $\mathrm{Ca}$ content either simultaneously or partially were significantly determined $A$. muelleri vegetative growth (Table 2). Based on the the model of $A$. muelleri vegetative growth, petiole height $(\mathrm{PH})$ was determined positively by age and monthly temperature $(\mathrm{R} 2=97.3 \%)$ with each regression coefficient 116.186 and 1.963 . This means that $97.3 \%$ of petiole height is determined by age and monthly temperature and the remaining $2.7 \%$ is explained by other factors not included in the model. Meanwhile, canopy diameter $(\mathrm{CnD})$ was 
determined positively by age and soil Ca content $\left(\mathrm{R}^{2}=\right.$ 93.3\%) with each regression coefficient 196.892 and 1.564 . And, bulbil number (BN) was determined by age, percentage of radiation and monthly temperature $\left(\mathrm{R}^{2}=\right.$ $88.8 \%$ ) with each regression coefficient $25.855,0.044$ and 0.085 . The models can be used to predict the optimal value of petiole height, canopy diameter and bulbil number because it had $\mathrm{R}^{2}$ value more than $80 \%$ and overall regression model assumptions are met (non multicollinearity, linear, homoscedaticity and normality of residual).

Table 2. The regression models of A. muelleri vegetative and corm growth

\begin{tabular}{lcc}
\hline Regression models & $\mathbf{R}^{\mathbf{2}(\boldsymbol{\%})}$ & Validity \\
\hline Vegetative growth & & \\
$\mathrm{PH}=116.186 \log \mathrm{A}^{* *}+1.963 \mathrm{~T}^{* *}$ & 97.3 & Valid \\
$\mathrm{CnD}=196.892 \log \mathrm{A}^{* *}+1.564 \mathrm{Ca}^{* *}$ & 93.3 & Valid \\
$\mathrm{BN}=25.855 \log \mathrm{A}^{* *}+0.044 \mathrm{PR}^{* *}-0.085 \mathrm{~T}^{* *}$ & 88.8 & Valid \\
& & \\
Corm growth & & \\
$\mathrm{CT}=0.069 \mathrm{PH}^{* *}+0.099 \mathrm{BN}^{* *}$ & 96.4 & Valid \\
$\log \mathrm{CD}=0.434 \log \mathrm{PH}^{* *}+0.29 \log \mathrm{BN}^{* *}$ & 99.6 & Valid \\
$\log \mathrm{CW}=1.091 \log \mathrm{CnD}^{* *}+0.765 \log \mathrm{BN}^{* *}$ & 99.1 & Valid \\
$\log \mathrm{CV}=1.090 \log \mathrm{CnD}^{* *}+0.052 \mathrm{BN}^{* *}$ & 97.7 & Valid \\
\hline
\end{tabular}

Note: PH petiole height; $\mathrm{CnD}$ canopy diameter; $\mathrm{BN}$ bulbil number; A age; T monthly temperature; Ca soil calcium content dan PR percentage of radiation; CT corm's thick; CD corm's diameter; CW corm's weight; $\mathrm{CV}$ corm's volume; ** the influence is very significant ( $\mathrm{p}$-value $<0.01$ )

In other research, Arisoesilaningsih et al. (2010) showed that altitude, monthly temperature, soil $\mathrm{Ca}$ content, cation exchange capacity (CEC) and percentage of vegetation cover were also significantly affect the bulbil number of $A$. muelleri. The difference result occurs because of the research using structural model with PLS Smart program. Analysis by PLS will have a structural model that can determine the variables that affect the other variables by considering one or more indicators. The structural model could not determine how much the $X$ value (predictor variable) is needed to optimize the $\mathrm{Y}$ value (response variable) or optimization, as well as regression models have.

Based on the results, optimization of A. muelleri vegetative growth using regression models can only be conducted on the observed age range, namely 1-4 years. After 4-year old, A. muelleri allegedly will enter the generative phase that produces flowers and fruit. During the generative phase, the food reserve in the corm is reduced so that corm has shrinkage and broken ( $\mathrm{S}$. Indriyani 2010, pers. comm.). Based on the regression model, if environmental factors are considered constant then $A$. muelleri vegetative growth maximum at the age of 4 years.

The evaluation of regression models indicate that petiole height, canopy diameter and bulbil number either simultaneously or partially were significantly determined A. muelleri corm growth (Table 2). Based on the model of A. muelleri corm growth can be explained that corm's thick
(CT) and corm's diameter (CD) were determined positively by petiole height and bulbil number with $\mathrm{R} 2=96.4 \%$ and $99.6 \%$ respectively. Meanwhile, corm's weight $(\mathrm{CW})$ and corm's volume (CV) were determined positively by canopy diameter and bulbil number with $\mathrm{R}^{2}=99.1 \%$ and $97.7 \%$ respectively. Additionally, the $\mathrm{R}^{2}$ value also exceed $80 \%$ and the overall regression model assumptions are met so that the model can be used to predict the growth of $A$. muelleri corm.

Based on the models, the number of bulbil has contribution to all corm growth variables (height, diameter, weight and volume). This is supports a research report of Arisoesilaningsih et al. (2010). Therefore, optimization of A. muelleri corm production should be consider all factors that influenced to amount of bulbil number, such as age, altitude, percentage of radiation, monthly temperature, $\mathrm{Ca}$ content of soil and CEC. In the meantime, the results are also accordance with the statement Ambarwati and Murti (2001) that the petiole height and canopy diameter have positive correlation significantly to the diameter and weight of $A$. variabilis corm.

The substitution between models in Table 2 obtained corm growth model related to environmental factor at $A$. muelleri agroforestry (Table 3 ). The model explains that the height and diameter of $A$. muelleri corm were determined by age, monthly temperature and percentage of radiation. Meanwhile, the weight and volume of $A$. muelleri corm are influenced by age, level of soil $\mathrm{Ca}$, monthly temperature and percentage of radiation.

Table 3. Model of A. muelleri corm growth related to environmental factors

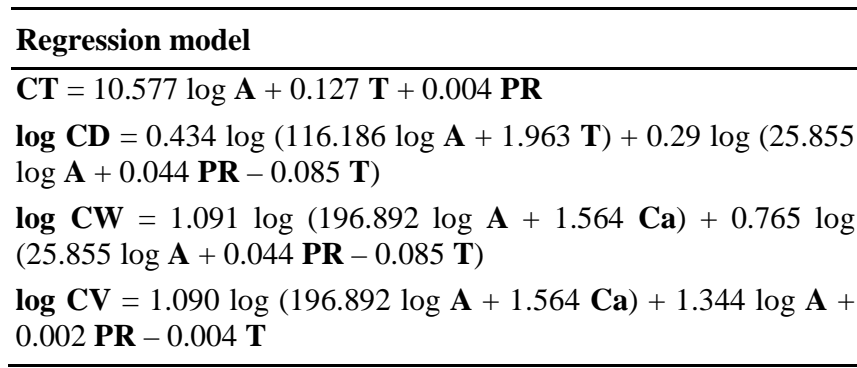

The fourth models emphasize that the physiological age of $A$. muelleri have important role on determine growth of A. muelleri vegetative and corm. Regarding to A. muelleri are perennial plants that may die or their corm to be shrunk and damaged after producing flowers and fruit, the growth of A. muelleri vegetative and corm are limited (S. Indriyani 2010, pers. comm.). Therefore, growth of both A. muelleri vegetative and corm will maximal after completing the fourth vegetative period or before entering the generative phase.

\section{Recommendations of harvest and habitat manipulation}

To meet the quality standards of A. muelleri corm match to market demand, the harvesting is done after corm's diameter more than $15 \mathrm{~cm}$ and weight minimum is 1-2 kg. A. muelleri corm on Sugihwaras Village, Klangon, Bendoasri and Klino are predicted to be harvested after 
Table 4. Prediction profiles of A. muelleri corm before and after manipulation in environmental variables at third and fourth period of vegetative growth in some agroforestry

\begin{tabular}{|c|c|c|c|c|c|c|c|c|}
\hline \multirow[b]{2}{*}{ Agroforestry } & \multirow{2}{*}{$\begin{array}{c}\text { Temperature } \\
\left({ }^{\circ} \mathbf{C}\right)\end{array}$} & \multirow[b]{2}{*}{ Radiation (\%) } & \multirow{2}{*}{$\begin{array}{c}\text { Ca content } \\
\left(\mathrm{me}^{-} \mathrm{hg}^{-1}\right)\end{array}$} & \multicolumn{2}{|c|}{ Corm's diameter $(\mathbf{c m})$} & \multicolumn{2}{|c|}{ Corm's weight (kg) } & \multirow{2}{*}{$\begin{array}{c}\text { Increasing } \\
(\%)\end{array}$} \\
\hline & & & & $\begin{array}{c}3 \\
\text { years }\end{array}$ & $\begin{array}{c}4 \\
\text { years }\end{array}$ & $\begin{array}{c}3 \\
\text { years }\end{array}$ & $\begin{array}{c}4 \\
\text { years }\end{array}$ & \\
\hline \multicolumn{9}{|l|}{ Before } \\
\hline Sugihwaras & 27.65 & 14,01 & 25.34 & 15.23 & 17.37 & 1.27 & 1.87 & 47.24 \\
\hline Klangon & 26.65 & 36.37 & 6.39 & 15.54 & 17.62 & 1.04 & 1.58 & 51.92 \\
\hline Kalirejo & 25.50 & 2.98 & 8,03 & $14.85^{*}$ & 17.00 & $0.97 *$ & 1.50 & 54.64 \\
\hline Bendoasri & 25.65 & 47.66 & 13.37 & 15.64 & 17.70 & 1.20 & 1.78 & 48.33 \\
\hline Klino & 23.39 & 59.33 & 13.26 & 15.60 & 17.64 & 1.25 & 1.84 & 47.20 \\
\hline \multicolumn{9}{|l|}{ After } \\
\hline Sugihwaras & 27.65 & from 14 to 60 & from 25.3 to 28.3 & 16.03 & 18.07 & 1.51 & 2.14 & 41.72 \\
\hline Klangon & 26.65 & from 36 to 60 & from 6.4 to 9.4 & 15.93 & 17.97 & 1.16 & 1.73 & 49.14 \\
\hline Kalirejo & 25.50 & from 3 to 60 & from 8 to 11 & 15.82 & 17.86 & 1.20 & 1.77 & 47.50 \\
\hline Bendoasri & 25.65 & from 48 to 60 & from 13.4 to 16 & 15.84 & 17.87 & 1.29 & 1.88 & 45.74 \\
\hline Klino & 23.39 & from 59 to 60 & from 13.3 to 16 & 15.61 & 17.65 & 1.31 & 1.90 & 45.04 \\
\hline
\end{tabular}

Note: * not meet standard qualification of A. muelleri corm

completing the third period of vegetative growth (Table 4). However, harvesting of the corm should be done after completing the fourth period of vegetative growth. It is caused by highly percentage increasing of corm's weight from third vegetative growth to fourth vegetative growth. Meanwhile, the A. muelleri corm on Kalirejo Village should be harvested after completing the fourth period of vegetative growth. It is caused corm production in third period of vegetative growth not meet the quality standard. In accordance with Ambarwati and Murti (2001), the larger the corm's diameter will be followed by the increase in corm's weight, which in turn increases the content of glucomannan. Therefore, the diameter and weight of corm can be used as a main selection of morphological characters in the harvesting of $A$. muelleri corm.

The optimizing A. muelleri corm production in the five agroforestries can be conducted by manipulation of some environmental variables. Environment variables are likely to be manipulated, which were percentage of radiation and soil Ca content. Based on regression models of $A$. muelleri corm growth, percentage of radiation and soil $\mathrm{Ca}$ content have a positive effect on the growth of $A$. muelleri corm so that both the value of these variables need to be improved. Increasing percentage of radiation can be done by pruning the shade canopy of $A$. muelleri. Nevertheless, the other research show that the higher light intensity will decrease plant height, growth of leaf and chlorophyll content of konjac plant (Liu et al. 1998), the A. konjac yielded 66\% more corms under $50 \%$ shade than without shade (Douglas et al. 2005) and A. muelleri showed positive response to suitable shading (Zhao et al. 2010). Santosa et al. (2006) also show that leaf size of $A$. muelleri increased with the increase in the shading level, resulting in the production of large corms at a low light intensity and corm reached a commercial size two years after planting under the $75 \%$ shading condition. Perum Perhutani of East Java (2008) explained that the minimum shade is required by $A$. muelleri for optimize the growth was $40 \%$ so that pruning can be done to generate $60 \%$ maximum exposure. In the meantime, the soil $\mathrm{Ca}$ content can be improved by the addition of lime on the land A. muelleri agroforestry. Douglas et al. (2005) show that lime and potassium increased yields but increasing rates of urea reduced yields after two season's growth of A. konjac. However, the addition of lime is recommended not exceeding 20 tons lime per ha because it can reduce the growth of corms. Addition of 20 tons of lime per ha can increase soil $\mathrm{Ca}$ content from 6.54 to 9.53 me.hg-1 or equivalent with 3 me.hg ${ }^{-1}$ (Sumarwoto 2004).

Based on those considerations, optimization A. muelleri corm production is recommended by improving percentage of radiation to $60 \%$ and soil Ca content increased 3 me.hg ${ }^{-1}$ than before (Table 4). The manipulation can increase corm's weight of A. muelleri is $3.26-23.7 \%$ from the previous (Table 5). The biggest increasing in corm's weight occurred in the Village Kalirejo. Meanwhile, the corm's weight increasing in Bendoasri and Klino Village not too high so that habitat manipulation is not necessary.

Table 5. Prediction of $A$. muelleri corm weight after habitat manipulation

\begin{tabular}{lcccccc}
\hline \multirow{2}{*}{$\begin{array}{c}\text { Agro- } \\
\text { forestry }\end{array}$} & \multicolumn{2}{c}{$\begin{array}{c}\text { Corm's weight (kg) } \\
\text { at 3 years }\end{array}$} & \multicolumn{3}{c}{$\begin{array}{c}\text { Corm's weight (kg) } \\
\text { at 4 years }\end{array}$} \\
\cline { 2 - 7 } & Before & After & $\begin{array}{c}\text { Increasing } \\
(\%)\end{array}$ & Before & After & $\begin{array}{c}\text { Increasing } \\
(\%)\end{array}$ \\
\hline Sugihwaras & 1.27 & 1.51 & 18.90 & 1.87 & 2.14 & 14.44 \\
Klangon & 1.04 & 1.16 & 11.54 & 1.58 & 1.73 & 9.49 \\
Kalirejo & 0.97 & 1.20 & 23.71 & 1.50 & 1.77 & 18.00 \\
Bendoasri & 1.20 & 1.29 & 7.50 & 1.78 & 1.88 & 5.62 \\
Klino & 1.25 & 1.31 & 4.80 & 1.84 & 1.90 & 3.26 \\
\hline
\end{tabular}

It should be noted that the pruning of canopy can only be done with permission Perum Perhutani because it was feared it would reduce productivity of stands. Therefore, to increase percentage of radiation can also be done by cultivation in a location that stand spacing is not too tight and the canopy of stand do not thick. Additionally, increasing of soil $\mathrm{Ca}$ content has a risk reducing $\mathrm{A}$. muelleri corm quality because the previous studies show that soil $\mathrm{Ca}$ 
content positively correlated with oxalate content in $A$. muelleri corm (Indriyani et al. 2010). The results Handayani (2009) also explained that the addition of lime (dolomite) in A. muelleri growth media can increase the density of Ca-oxalate crystals in A. muelleri leaves. Nevertheless, the results of research Sumarwoto (2004) explains that the addition of 20 tons of lime $(\mathrm{Ca}) /$ ha can also increase soil $\mathrm{pH}$ from 4.55 to 5.99 . Given that the $\mathrm{pH}$ is negatively correlated with oxalate content in A. muelleri corm (Indriyani et al. 2010), it is necessary to ensure on the continued study about the relationship between the increase of $\mathrm{pH}$, soil $\mathrm{Ca}$ content, corm production and decreasing oxalate content in A. muelleri corm. Furthermore, in structural model using PLS, Indriyani et al. (2011) explained that corm oxalate content of A. muelleri was determined directly by temperature and soil CEC. Therefore, optimization A. muelleri corm production by improving percentage of radiation and soil $\mathrm{Ca}$ content can be conducted in A. muelleri agroforestries.

\section{Selection of new habitat for $A$. muelleri agroforestry}

Optimizing the A. muelleri corm production for new agroforestry can be conducted by controlling the vegetative growth by choosing a new agroforestry has character monthly temperature, percentage of radiation and soil $\mathrm{Ca}$ content are optimum. To achieving monthly temperature optimum, A. muelleri better planted in agroforestry with low altitude, for example in the village of Sugihwaras (Arisoesilaningsih et al. 2010). Meanwhile, maximum of radiation $(60 \%)$ can be achieved in agroforestry with stands not too tight. Additionally, soil $\mathrm{Ca}$ content can be optimized so that CEC to be optimal, like Sugihwaras Village. The increasing of $\mathrm{Ca}$ content can be done with calcification (Sumarwoto 2004).

\section{CONCLUSION}

The multiple regression analysis of Amorphophallus muelleri growth at some characters agroforestry and age showed high validity with $\mathrm{R}^{2} 88-99 \%$. Regression model showed that age, monthly temperature, percentage of radiation and soil $\mathrm{Ca}$ content either simultaneously or partially determined the growth of A. muelleri vegetative and corm. Based on these models, the A. muelleri corm reached the optimal growth after four years of cultivation and they will be ready to be harvested. Additionally, the soil Ca content should reach $25.3 \mathrm{me}^{\mathrm{hg}} \mathrm{g}^{-1}$ as Sugihwaras agroforestry, with the maximal radiation of $60 \%$.

\section{ACKNOWLEDGEMENTS}

This research was supported by Directorate General of High Education (DP2M) through Indonesia Managing Higher Education for Relevancy and Efficiency (IMHERE) of Department of Biology, Brawijaya University through Staff Research Grant year 2009. We would like to thanks to Dr. Serafinah Indriyani for helpfully assistance at the field.

\section{REFERENCES}

Ambarwati E, Murti RH. 2001. Correlation analysis and path coefficient of agronomy character on chemical composition of iles-iles (Amorphophallus variabilis) corm. Agric Sci 8 (2): 55-61.

Arisoesilaningsih E, Indriyani S, Retnowati R, Fernandes AAR. 2010. Modelling growth of Amorphophallus oncophyllus corm at some agroforestry in East Java using smart PLS. In proceeding Book Volume $1.7^{\text {th }}$ Basic Science National Seminar. Faculty of Mathematics and Natural Sciences, Brawijaya University, Malang, 9 March 2010. [Indonesian]

Bayu. 2008a. Ambico ambition on porang processing. www.byufitrah.militanunair.com

Bayu. 2008b. Porang, a hidden treasure in jungle. www.byufitrah.militanunair.com

Budiman, Indriyani S, Yanuwiadi B, Arisoesilaningsih E. 2010. Profile of Amorphophallus muelleri habitat and growth in East Java. I:n Proceeding of International Conference of Global Resource Conservation. Faculty of Mathematics and Natural Sciences, Brawijaya University, Malang, 9 July 2010. [Indonesian]

Douglas JA, Follett JM, Waller JE. 2005. Research on konjac (Amorphophallus konjac) production in New Zealand. International symposium on root and tuber crops of International Society for Horticultural Science, Palmerston North, New Zealand, 25 April 2005.

Hair JF, Anderson RE, Tatham RL, Black WC. 1998. Multivariate Data Analysis. $4^{\text {th }}$ ed. Prentice Hall Inc, New Jersey.

Handayani R. 2009. The influence of lime (dolomite) toward shape, size and density of calcium oxalate in porang leaf. [Bachelor Thesis]. Brawijaya University, Malang. [Indonesian]

Hasan MI. 2008. The principal of statistics inferensive. PT Bumi Aksara, Jakarta.

Indriyani S, Arisoesilaningsih E, Wardiyati T, Purnobasuki H. 2010. The relationship of the environmental factors of porang (Amorphophallus muelleri Blume) habitat at five agroforestry in East Java related to corm oxalate content. In: Proceeding Book Volume 1. $7^{\text {th }}$ Basic Science National Seminar. Faculty of Mathematics and Natural Sciences, Brawijaya University, Malang, 9 March 2010. [Indonesian]

Indriyani S, Arisoesilaningsih E, Wardiyati T, Purnobasuki H. 2011. A model of relationship between climate and soil factors related to oxalate content in porang (Amorphophallus muelleri Blume) corm. Biodiversitas 12 (1): 45-51.

Jansen PCM, van der Wilk C, Hetterscheid WLA. 1996. Amorphophallus Blume ex Decaisne. In Flach M, Rumawas F (eds.). Plant Resources of South-East Asia No 9: Plant yielding non-seed carbohydrates. Prosea, Bogor.

Liu PY, Zhang SL, Zhang XG. 1998. Research and utilization Amorphophallus in China. Acta Botanica Yunnanica 10: 48-61.

Perum Perhutani of East Java. 2008. Porang cultivation. Perum Perhutani, East Java. [Indonesian]

Perum Perhutani of KPH Saradan. 2007. Developing of porang plants. Perum Perhutani, Saradan, East Java. [Indonesian]

Prihatyanto T. 2007. Cultivation of star fruit and porang to increase prosperity of forest edge society. The Ministry of Forestry. [Indonesian]

Santosa E, Sugiyama N, Nakata M, Lee ON. 2006. Growth and corm production of Amorphophallus at different shading levels in Indonesia. Nettai Nogyo 50 (2): 87-91.

Sumarwoto. 2004. The effects of liming and bulbil sizes on the growth of iles-iles (Amorphophallus muelleri Blume) in high level of $\mathrm{Al}_{\mathrm{exc}}$ soil. Agri Sci 11 (2): 45-53.

Sumarwoto. 2005. Iles-iles (Amorphophallus muelleri Blume): Description and another character. Biodiversitas 6 (3): 185-190. [Indonesian]

Suryadi D. 2008. Local wisdom to develop green forest and prosperity. www.kabarindonesia.com

Zhang DH, Wang QP. 2010. Biology characteristic and prospect of Amorphophallus muelleri in plantation of konjac. J Changjiang Veget (22): 71-73.

Zhao J, Zhang D, Jianping Z, Srzednicki G, Borompichaichartkul C, Kanlayanarat S. 2010. Morphological and growth characteristics of Amorphophallus muelleri Blume: a commercially important konjac species. Southeast Asia symposium on quality and safety of fresh and fresh-cut produce of International Society for Horticultural Science, Bangkok, Thailand, 29 October 2010. 